THE NEGRO MIGRANT IN ST. IOUIS

by

Prisoilla Alden Stith, A.B.

SUBMITTED IN PARTIAI FULFIIIMENT OF THE

REQUIREMENTS FOR THE DEGREE

OF

MASTER OF ARTS

in the

GRADUATE SCHOOL

of the

UNIVERSITY OF MISSOURI

1918

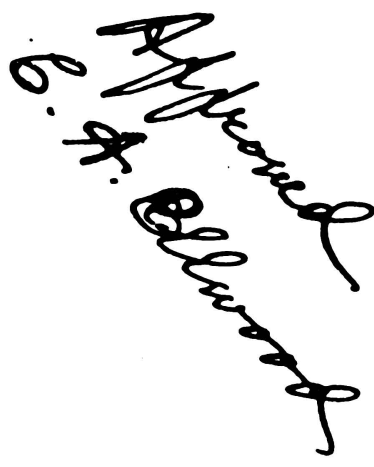




\section{THE NEGRO MIGRANT IN ST. LCUIS}

Table of Contents

I. Introduction.

II. The Migrant.

1. Volume of Migration.

2. The migrants themselves.

3. Reasong for migrating.

4. Places from which the migrants come.

5. Length of time in St. Louis.

6. The migrants' attitude toward St. Louis.

7. Conditions of migrant negroes in St. Louls.

a. Description of negro sections.

b. Housing conditions.

c. Industrial opportunties.

d. Education and Religion.

e. Recreation.

f. Health.

III.Problems of community interest aggravated by the negro migration.

1. Bad housing conditions.

2. Health.

3. Inadequacy of constructive forces for the negro. IV. Recommendations and Conclusion. 


\section{INTRODUCTION.}

General Surver.

The last few years have witnessed a marked migration of negroes to the city of St. Louls, from throughout the South and Prom East St. Iouis. Such an influx brings with it many problems and increases the complexity of difficulties already present in a community. Any strangers in a city may find it hard to adjust themselves to new conditions, but this fact is especialIy true of the negro. He is not handicapped by ignorance of our language and customs, as the foreign Immgrant is; but the colored mlgrant has not the same opportunities in industry, recreation and education that the white person has. Then too, little if any constructive work is done for the negro, and the same interest is not shown in righting the maladjustments of the colored people as those of the forelgners among us. Not only is there indifference to the colored race but also a definite antagonism; for example, there is only one hospital in St. Iouls, excluding the City Hospital and its divisions, and one small colored hospital, which makes any provision for negroes. St. Louis ranks fourth among northern cities in 
its negro population; in 1910 Chicago and St. Louls were about equal on this point, but the rate of increase of the negro population of Chicago is almost twice that of St. Louis. *It was the opinion of 10cal colored men in both cities several years ago, that Chicago offered greater freedom and opportunities than St. Louis; this fact may be due to northern tolerance of the negro, to the wider fields of industrial opportunities or to the fact that st. Louis. Is not 80 cosmopolitan a city, but is still largely influenced by southern traditions.

\section{Purpose of study.}

The purpose of this investigation is to ascertain the conditions of negro migrants in this city, and to learn what additional opportunities they need. Migration to the city will not be seriously diminished by allowing undesirable conditions to remain unchanged, but such a policy will do the megro much harm. It is only fair to the migrants and to the community as a whole that every effort be made to promote the welfare of the newcomers.

*Crossland: St. Louis. p. 10. 


\section{Scope and Method.}

This study is intended to cover the migration of negroes who have come to St. Iouls from January 1917 to April 1918. General information about the negro migrants was obtained from the Division of Health and the Board of Education of the city, and from such private organizations as the Metropolitan Iife Insurance Company, The Colored Women's League, etc. An Intensive study was made by the Missourl School of Soctal Economy of three hundred migrant families, but this thesis is based on the facts taken from one hundred and ninety three selected schedules, although in some cases the tables are based on a larger number. (See schedules or information blanks on following pages)

It $w 111$ be seen that these schedules emphasize such points as composition of family, previous residence, reasons for migration, housing conditions and recreational, educational and industrial opportunities in st. Iouis. The names of migrant families were obtained from school prinolpals working in the districts where the migrants had largely settled. Although some of these families Iive in the outlying negro districts, the great majority now reside in the localities studied and therefore the statistics gathered are typical of the general group of 
MISSOURI SCHOOL OF SOCIAL ECONOMY

NEGRO MIGRATION IN ST. LOUIS, 1918

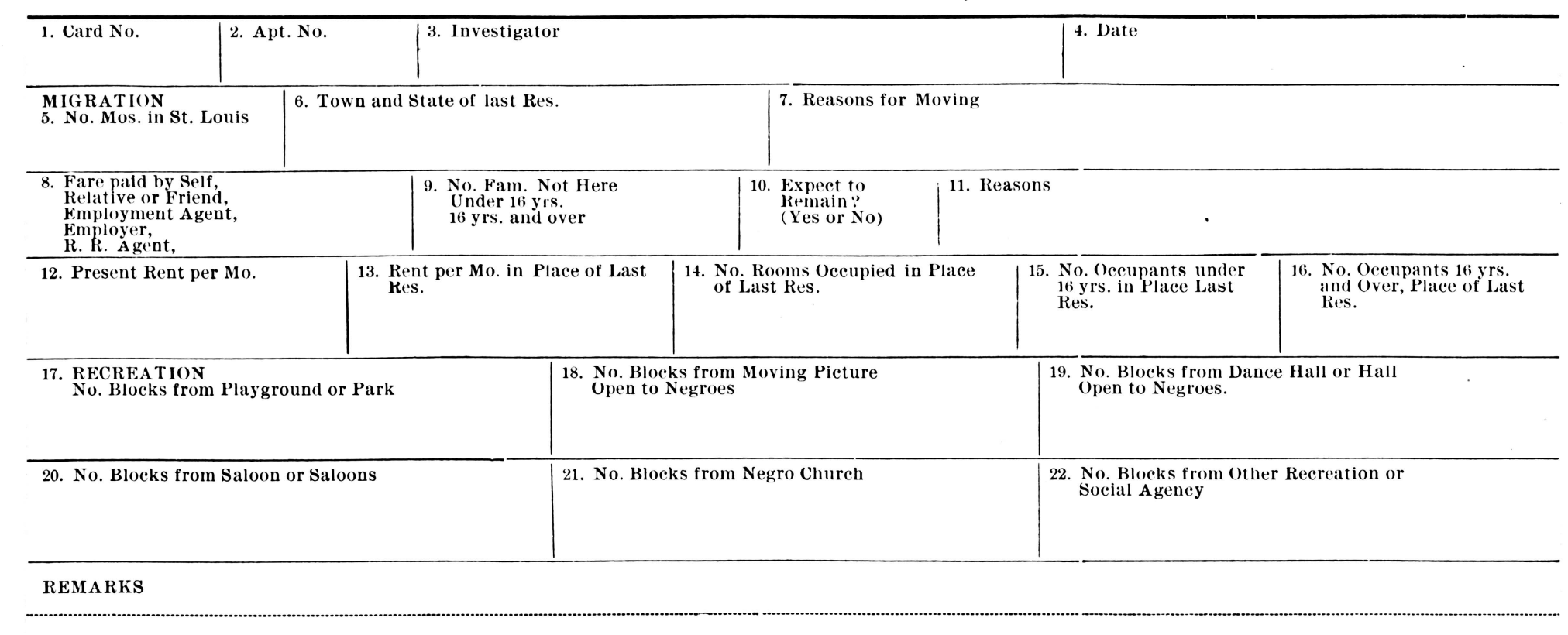

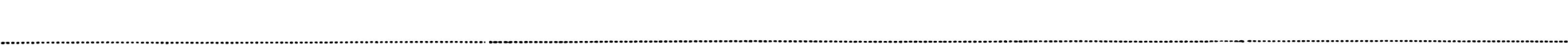




\section{EMPLOYMENT AND EDUCATION OF MEMBERS OF HOUSEHOLD}

\begin{tabular}{|c|c|c|c|c|c|c|c|}
\hline Family & Age & Civil State & Occupation or School Grade & Co., Firm or School & $\begin{array}{c}\text { Wage by } \\
\text { Week or Day }\end{array}$ & $\begin{array}{l}\text { No. Days } \\
\text { Work per } \\
\text { Week }\end{array}$ & $\underset{\text { To }}{\text { Hours From }}$ \\
\hline \multicolumn{8}{|l|}{ Man } \\
\hline \multicolumn{8}{|l|}{ Woman } \\
\hline \multicolumn{8}{|l|}{1} \\
\hline \multicolumn{8}{|l|}{$\underline{2}$} \\
\hline \multicolumn{8}{|l|}{3} \\
\hline \multicolumn{8}{|l|}{4} \\
\hline \multicolumn{8}{|l|}{5} \\
\hline \multicolumn{8}{|c|}{ Da } \\
\hline \multicolumn{8}{|c|}{ PLACE OF LAST RESIDENCE. } \\
\hline \multicolumn{8}{|l|}{ Man } \\
\hline \multicolumn{8}{|l|}{ Woman } \\
\hline \multicolumn{8}{|l|}{1} \\
\hline \multicolumn{8}{|l|}{$\underline{2}$} \\
\hline \multicolumn{8}{|l|}{3} \\
\hline \multicolumn{8}{|l|}{4} \\
\hline \multicolumn{8}{|l|}{5} \\
\hline 6 & & & & & & & \\
\hline
\end{tabular}


MISSOURI SCHOOL OF SOCIAL ECONOMY

HOUSING INVESTIGATION OF ST. LOUIS, 1918

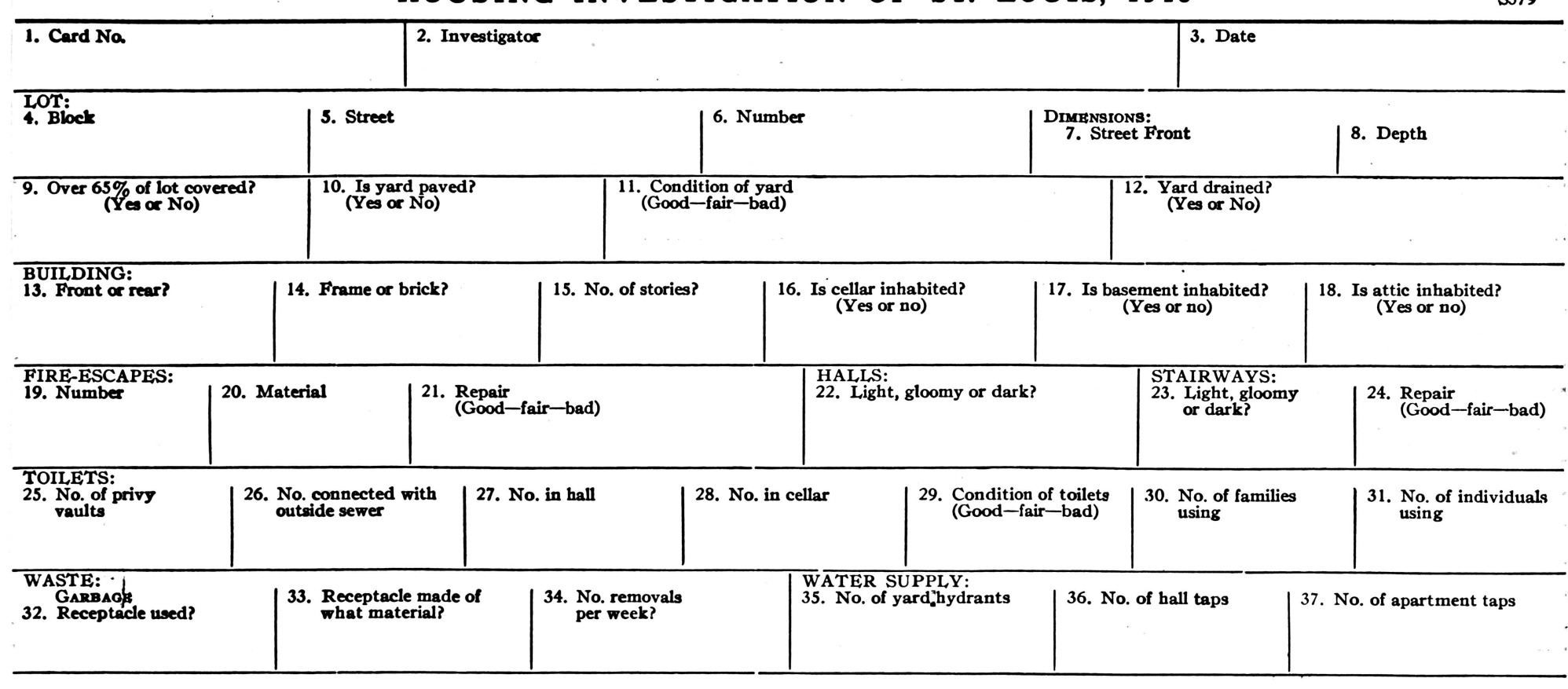

38. REMARKS: 
FACTS ABOUT EACH APARTMENT

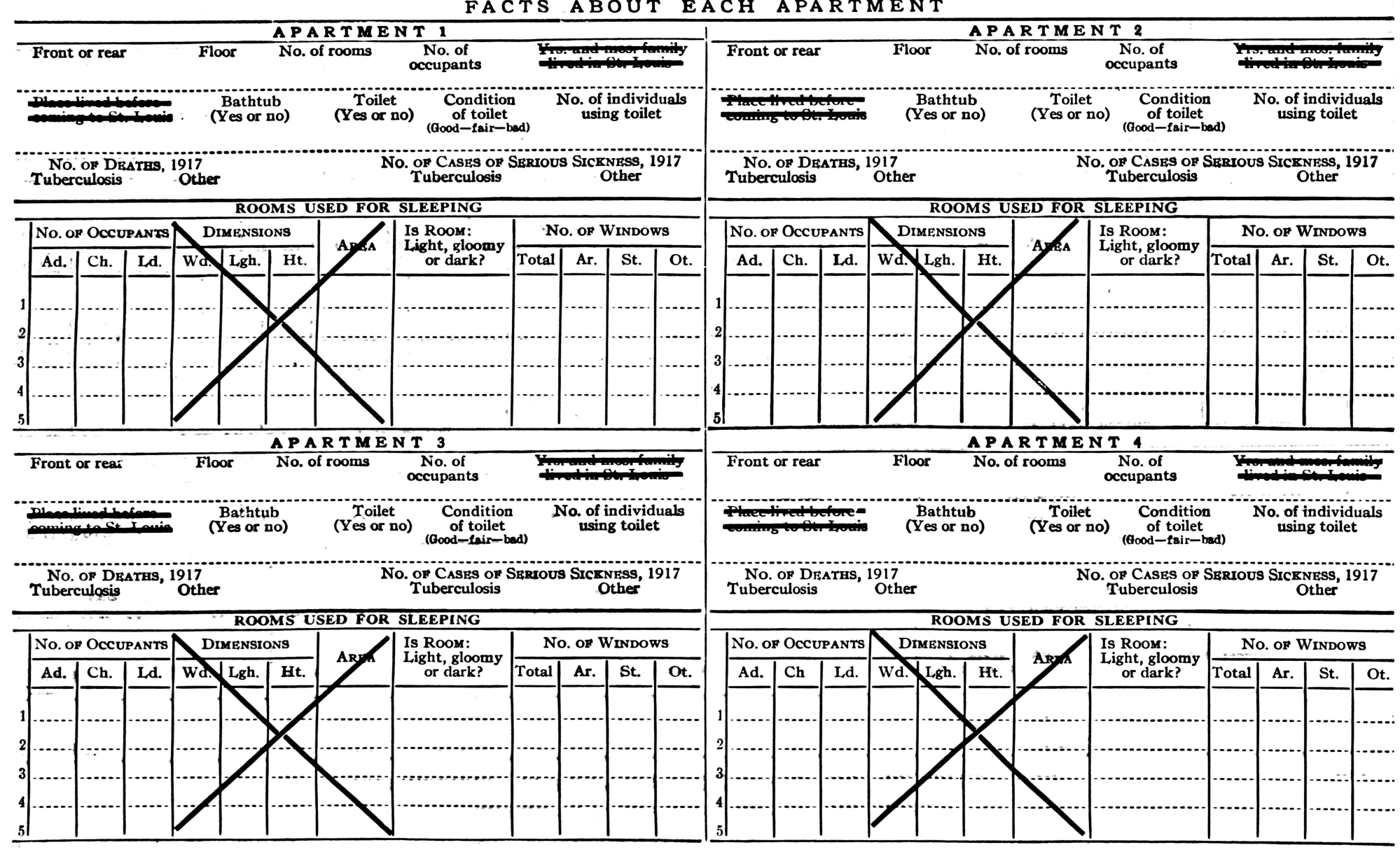


migrant negroes.

Attitude of the Families studied.

The attitude of the colored migrants interviewed in this investigation is significant of the varied influenoes that have surrounded them. Some are indifferent and answer all questions without even seeming to wonder why they are asked, but never question the investigator's right. Some are suspicious, and so afraid that harm will oome to them that they do not tell the truth. This attitude is especially characteristic of those migrants from East st. Iouis. One woman, when asked if she came from East st. Louls, denied it emphatically; but after a more friendly relation had been established and the purpose of the investigation was explained she forgot her denial and said she came over the river at the time of the riot. We were told by a relative and neighbor that another migrant had come from East St. Louis; but she swore she had lived on this side all her I1fe, and no amount of explanation could convince her that there was nothing to fear.

Some of the men and women interviewed were curious to know the purpose of the schedules, but when they understood they were interested and anxious to make the work as easy as possible. Others were antagnaistio and 
evasive, and each bit of information was reluctantly given. One old southern darky answered all the questions quietly and politely, and then inquire as to the purpose of the schedules. Then the reasons for the investigations were explained she was almost childishly pleased. The idea that some one was taking an interest in the welfare of her people seemed a new one to her and it was warmly appreclated. One colored landlady who happened to be on the premises of a ramshackle house and who evidently believed that the investigator came with malevolent intent, put in a good word for her class. "Now remember" she told the investigator, "these are pore people; so have charity honeg, have charity." These illustrations of the conduct and misgivings of migrant negroes indicate the difficulties encountered in obtaining accurate and unbiased information, but in most cases these prejudices were overcome and it is belleved that spbstantially correct statements were secured.

II. MHE MIGRANT.

Volume of the Migration.

It is difficult to estimate with any degree of accuracy the volume of the negro migration, but an ap- 
proximate figare can be obtained. The natural rate of increase of the negro population, based on the census of 1900 and 1910, 18 2.38 per cent per year. According to this rate in eight jears there would be an increase of 19.04 per cent; since the number in 1910 was 43,960 , the population in 1918 must be approximately 52,330 , excluding any increase die to migration. *The registration of colored school chilaren in 1910, for elementary and high schools, was 6,342 , or 14.4 per cent of the total negro population. **The registration in April 1918 was 10,442, and assuming that this latter figure bears the same ratio to the total poprlation as the registration in 1910 bore, the negro population of st. Iouis today is approximatily 72,514. Thus the increase due to migration is represented by the difference between 72,514 and 52,330, which is 20,184. The migration from East st. Iouis in July 1917, following the riot there, is the largest single factor.***he Division of Health estimates, from the number of vaccinations necessitated by the influe of negroes, that at least 7,000 persons came across the river in Julg.

*Board of Education; Fifty sixth annual- report pp270-73 ** " " ***Dr. Woodruff: Department of Infectious Diseases. 
*The Metropolitan Iife Insurance Company reported an increase of 6,000 in the number of policies held by negroes from October 1916 to October 1917, and credited the migration from East St. Louis fith the responsibility for the greater part of the increase. The number of policies in 1916 was 60,000 ; in 1917 it had risen to 66,000 , which eigure the lietropolitan considered approximately the same as the negro population at that time. The number not insured in their company Is to some extent offset by the number holding more than one policy. No definite figures were obtainable on this point, but it is claimed that it is quite a common occurance for one negro to hold two or three pollcies for himself alone, and that usually every member of the family is insured. The opinion of colored social workers of the St. Louis Provident Association, and of other negroes interested in work of that nature, confirmsthe statement that a great majority of the negroes in the city carry industrial insurance; however negroes in the well-to-do class,**wich comprises about 5,000 persons, do not as a mile carry this type of insurance.

* Supt. Metropolitan Iife Insurance Co. **Based on Crossland's estimate of the professional class of negroes and the average size of family. 
*In May 1918 the Metropolitan Iife Insurance Company reported 14,840 negro familles of policy holders. Statistics of the individual policy holders were not available at that time, but by computing the average size of negro families in St. Louis an estimate can be made of the present number. The average size of the migrant famifies studied was 4.1 , and that of fifty selected families whose histories are recorded by the St. Louis Provident Association was 3.98 , narly 4. The evidence points to the conclusion that the migrant families are smaller than the average for all families in St. Louis, which in 1910 was 4.4, because a large propostion of the adults are young couples whose families are not jet completed. If so, we may assume that the average negro family in St. Louis consists of about 4.5 persons. The 14,840 families insured at present by the Metropolitan Iffe Insurance Company then contained about 66,780 persons. To this number should be added the estimated 5,000 well-to-do negroes not carrying industrial insurance; the resulting figure is 71,780 , which does not diviate widely from the estimate based on the school popalation.

* Supt. Metropolitan Iffe Insurance Co. 
The Migrants Themselves.

Composition of Family.

The migrants themselves are of great interest to us, as they are new residents and citizens of our community and will naturally have some influenoe, howeter slight. It is usually true of migrations that a large proportion is made up of single men or married men who have come without their families, expecting to send for them later. However, our investigation of migrants in st. Iouis does not show this condition to be true to so great an extent as might be expected. This fact may be partly accounted for by the way in whioh those migrants studied were discovered, namely, through the school principals, who naturally came more closely in touch with families than with single men. Then too, there were many cases where the man came to the city first and had already sent for his family.

The size of the family among the migrants varied greatly and no one particular type seemed to predominate. There is a good proportion of young married couples, some with a few children, but many with none; on the other hand many large families are also represented. In the large families it is very rare that any members have remianed at their previous residence; if any, usually all of the children have come. In some cases the father and 
mother precode the children to establish a home before sending for them. Often it happens that a grown son or daughter comes to St. Louls and later sends for the mother, especially when the latter is a widow. In twenty-five families of those studied some members have been left at the previous residence; they number fifty per sons in all, twenty theee of them sixteen years and over, and twenty seven under sixteen.

\section{Types of Migrants.}

In our personal investigation many different kind of people were found among the migrants. On the whole they may be divided into two classes: first, those who came as a result of real, intelligent thinking and reasoning; who know why they came an have a definite idea whether they are going to remain or not. Second, those migrants who aree characterized by a general indefiniteness of purpose and apparent absence of thinking power. They cangive no reason for coming to St. Louis, or for leaving their old home, except that as several said, they just "took a notion". This is the type we hear criticized rather harshly for the restlessnees and instability which prompt them to migrate northward. However, this class is not so large as appears on superficial investigation, because many negroes undoubtedly had a purpose in migrating, but for some rea- 
son or other refused to disclose it. This determination not to give their reasons for coming, for fear of arrest or other harm, came indirectly to the attention of the invertigators, and attempts were made to secrre better corporation.

There is a great deal of difference in the way these two types of migrants accept the new conditions under which they are living. The lattertype accept everything without question, taking things as they come as a natural part of oity life; the parents take no interest in their children's sohool lffe, do not know what grade or room they are in, and often are even 1gnorant of the name of the school. The more intelligent class often rebel against the treatment they recaive, especially from landlords, who refuse to remedy bad conditions of the houses, yards and plumbing. The parents show an interest in the education of their children; can give any desired information about the sohools, and often speak of the better educational advantages here than those afforded in the south. They speak of the changed industrial conditions, such as shorter hours, better wages and easier work. Former farmers especially appreciate the fact that they are really oarning wages, and 
their income exceeds their expenditures; on the farm they barely existed. Even though some of these people realize that the cost of living is higher here than in the south, and that their net gains are very little larger, they are more contented here. Reasons for Migrating.

In general there are several main reasons for the migration of negroes from the south; first, indastrial causes; these include dissatisfaction with low wages; hopes of better wages in the north, often founded on tales of friends and relatives who have already migrated; better industrial opportunities for negroes in northern sities; the influence of labor agents working in the south to stimulate migration of negro labor; and importation of negro labor by employers. Second, economio pressure: this is especially due to failure of orops and to the mortgage system of farming. Third, the influence of friends and relatives: many have come to st. Ioufs and write home telling of the high wages and better living conditions, and some merely want their relatives to join them. Fourth, a desire to better their condition generally, not only by seeking higher wages, but through better school facllities, greater freedom and more fair political and judicial rights. This is 
one cause that influences the better type of negro, who thinks out his problems and seeks to solve them. Fifth, and last of the main reasons, is an element of wonderlust; a desire to travel and see city life. The cause of the migration from East st. Louis was in practically all cases the riot of July 1917.

TABLE NUMBER I.

Showing causes of migration of negro families to St. Louis (193 cases)

Causes

Total .

East St. Louis riot

Better wages

Influence of Relatives or Friends

Better Schools

Poor Crops and the Boll Weevil

Dissatisfaction with conditions in South

General Exodus

Importation and agitation by Labor Agents

Tired of farming

Poor Health

Miscellaneous
Ho. in fam.

*224

43

70

42

14

10

11

7

4

5

2

16

* This total is greater than the number of cases because when more than one important reason was given both were recorded. 
With regard to the reasons why the colored people left the south, some interesting information was obtained from *Misa Elizabeth Moore, Economic Secretary of the Wheatley (Colored) Branch of the Young Women's Christian Association. While in Nashville, Miss Moore was one of the representatives at a conference of the Board of Trade and the Chamber of Commerce, the purpose of which was to determine why the negroes were leaving Nashville in such great numbers. After a thorough investigation it was found that there were five principal causes for the migration. First, Poor school facilities, second, Low wages, third, Lack of Justice in the Courts, fourth, Lack of Guarantee of Iife and Property and fifth, unfair political rights. The complaints of the negroes against the schools were; that the term was too short, especially in the country shools; that the teachers were inefflolent; and that the colored children were denled some

*Miss Moore is a graduate of Fisk University, and has taken post graduate courses at Columbia University, N.Y. She taught Cirlos and allied subjects in the colored high sohool in Nashrille, Tenn. for over $10 \mathrm{yrs}$, , but finally left because of the inadequate salaries paid. 
of the courses open to white children. The more intelligent negroes are beginning to realize that education will help them solve their problems, and they are rebelling against the apparent attempt to keep them ignorant. The expression of one colored farmer who was leaving for the north, was found to be typical of many. When asked why he was leaving he gave several reasons, ending with: "I want my children to have a better chance than I've had."

Iow wages, or as many colored men expressed it, "not a living wage", was the cause of much of the migration. In a large rock quarry in Nashville the workers struck, demanding ten cents a jard increase; when the foreman tried to argue with them, they stood firm, saying that if they did not get their demand they would leave in a body that night. Every man there had work promised him in some northern oity. In this instince the men were granted the increase, but often the dissatisfaction did not culminate in a strike and the men moved north.

Laok of full political rights was another cause of dissatisfaction; in Tennessee negroes are not allowed to rote in Democratio primaries, and in some other southern states they have no political rights whatsoever. The negro naturally resents this "taxation without repre- 
sentation" and turns to that part of the country where he can expect fair political rights.

To 1llustrate the injustice of the : law toward negroes, Miss Moore cited the experiences of several persons she knew. An influential colored man of Nashville was walking along the street at night with rather a handsome coat on his arm. He had escorted a young girl home from his sister's party;/she had worn no wrap, his sister had loaned hers, and he was bringing it home. A policeman saw him and cried, "Halt!" The man did not realize that he was the object so continued. The officer finally stopped him, demanded to know whose coat he was carrying, and when told called the man a liar. NNo nigger ever had a coat like that" he said, and arrested the man. He was kept at the police station over an hour before the officer even tried to clear the matter by telephone; then it was settled 1mmediately and the man was released but his name went down on record for ninsubordination." Cedar Street in Nashville is a kind of rendezvous for the negroes similar to parts of Market street in St. Iouls, and in the noon hour many people congregate there. One day several prejudiced sheriffs arrested sorenty negroes at once for vagrancy; the efforts of a prominent colored man secured the release of all of them, but 
did not remove the humiliation, or the prejudice that caused the trouble. Some of those arrested were chauffeurs, andmail clerks, and all were respectable, lawabiding men. During the time when many soldiers were stationed in Nashrille, conditions became rather ser10us. The central station where all trollgy lines of the city meet is always a busy place, and the treatment of the negroes by the soldiers was disgraceful. The would pash negroes aside, knock them out of their way, and in several cases slapped negro women. This treatment infurtated the colored people and the "riff raff" among them got together and marched into the station armed with knives and clubs. Only the intervention of the better element of the colored and white people prevented a riot. To maintain peace in the future the federal government placed guards in the station and since this uprising the negroes have received much better treatment.

Iynching is the most extreme form that the prejudice against the negro has taken, and many colored persons have been lynched and their innocence proven afterwards. Although this evil is diminishing, it has left its effects stamped on the white and colored alike. Such inhumane treatment as the negroes have endured in 
the past has degraded the white people who tolerate it, and has of course intimidated and embittered the negro. An intelligent colored woman gave her explanation of the negro problem in the south; it is not particularly original but interesting from her point of view. Before the civil war the negro slaves lived in close touch with the luxury of the aristocracy of the south, and looked down on the "poor white crackers" and despised them. After the war the aristorcratic white class was crushed and the common white people gradually became influential. This is the class that works injustice to the negro, in retalliation for the old bitter feeling between them; and the only blame that can be laid to the door of the better white people is that of silence and toleration of the unjust treatment of the negro. It is the opinion of this thinker that the "aristocracy" is waking up and that conditioms of the negro in the south as well as in the north will improve steadily and rapidiy. The causes of migration throughout the southern states are practically the same as those in Tennessee. The south is undeniably backward in its educatiomal progress, and especially are the faoilities for the negro inadequate. The school term is short; the teachers are often ignorant and poorly paid; and the amount of free 
education for colored children is limited. In New Orleans only six grades are taught, and in Atlanta, eight grades, Many places have such restrictions, and where there are colored high schools the same courses are not offered as are given in the white schools.

The ignorance of the negro leads to his exploitation, as in the mortgage sjstem of farming. The crop is mortgaged before it is grown, and if the ignorant farmer is dealing with a keen unscrupulous person, he is often outwitted. The amount of the mortgage is:usualiy set in terms of produce such as bales of cotton, and not in money, and this offers an opportunity for exploitation of the farmer who doesn't know the value of his produce, or who does not understand business transactions. Thas it often happens that at the end of the year the farmer finds that he has gained nothing, and a new mortgage is necessary. mhis system is discouraging to farmers, besides offering littie or no incentive to work. If more farmers owened their land this mortgage difficulty would not be so important, but in some states it is mace very hard for them to acquire small farms. In Alabama there is a law against breaking up large plantations into small lots. This situation has been partiy met by the extension work of Taskegee Institute, Alabama, in which large 
tracts of land are purchased and divided into small farms for negroes. The result is a prosperous farm colony where the people have their own schools: and churches, and are very happily situated. It is significant that the negroes from this region are not leaving for the north.

*Mr. Haines, in his article "Negroes Move North" gives a splendid discussion of conditions in the south which are causing the migration. "The divorce of the negro from the soil and the call of commercial and infustrial centers were the economic influences moving him.... To these economic forces were added social and individual causes, such as the strained relation of landlords and tenants on southern plantations; "Jim Crow" legislation and other restrictions of the rights and privileges of persons of color. Influences such as the coming of labor agents, going north to join relatives, were noted as moving causes." The study is made very attractive by the local colior throughout, and it gies a clear pibture of conditions.

*Haines,Geo. Edmund. Negroes Move North. Part I.The Surveg Mag 4. pp. 116-17. 
Where the Migrants Come From.

Although practically every part of the central

south has contributed to the migration movement, among those families studied certain districts have a larger representation than others. Mississippi, Tennessee, and Alabama, especially the farming regions around the larger clties, furnish a large proportion; many came from Arkansas, Kentucky and Louistana and a few from Georgia, Texas, Oklahoma, Florida, Missouri and Ohio. A greater number of migrants came from East St. Louis than any other single place, but only one or two families came from other parts of Illinois.

TABIE NUMBER II.

Showing States represented in Migration of 267 families.

\begin{tabular}{|c|c|c|c|}
\hline states & $\begin{array}{l}\text { Number } \\
\text { Fam }\end{array}$ & $\begin{array}{l}\text { of } \\
\text { Ind }\end{array}$ & per cent \\
\hline $\begin{array}{l}\text { Total }=-1 \text { all states } \\
\text { Mississippi } \\
\text { Illinoig(mostlyB. St. I } \\
\text { Tennessea } \\
\text { Alabama } \\
\text { Arkansas } \\
\text { Zentucky } \\
\text { Iouisiana } \\
\text { Missouri } \\
\text { Texas } \\
\text { Georgia } \\
\text { Flordia } \\
\text { Oklahoma } \\
\text { Ohio }\end{array}$ & $\begin{array}{r}267 \\
106 \\
51 \\
43 \\
23 \\
15 \\
7 \\
6 \\
5 \\
4 \\
3 \\
2 \\
1 \\
1\end{array}$ & $\begin{array}{r}1101 \\
485 \\
230 \\
131 \\
96 \\
50 \\
30 \\
20 \\
18 \\
15 \\
13 \\
9 \\
2 \\
2\end{array}$ & $\begin{array}{r}100 \\
44.05 \\
20.90 \\
11.90 \\
8.71 \\
4.55 \\
2.73 \\
1.81 \\
1.63 \\
1.36 \\
1.18 \\
.82 \\
.18 \\
.18\end{array}$ \\
\hline
\end{tabular}

in St. Louls varied from one week to two jears. Many of 
them have jot been here long enough to become acollmated, and they know very little of the city. On their arrival they seem to settle in a rut, and make no attempts to learn the opportunities and resources of their new home.

$$
\text { Migrants opinions of st. Iouls. }
$$

It is interesting in the light of community problems, to notice the attitude of the migrants toward their new place of residenco.

TABIE NUAIBER III.

Showing number of migrant families expecting to stay in St. Ionis.

Decision

Total

Expect to stay

Do not expect to stay

Uncertain
Numbers of Families

193

131

33

29
Ber Cent

100

68

17

15

A large proportion expect to remain here; some because they like it or are satisfied; some because of better industrial conditions; some because of improved school facilities; and others because they have friends and relatives here. A number have not yet decided whether they will remain, and are just staying on to give St. Louis a chance to prove itself better than the old home. In some 
of these families a conflict of opinion between the members was responsible for the indecision; often the husband was satisfied with his work and wages, but the wife did not like the city life, the bad housing conditions and the high cost of living.

TABLE NUMBER IV.

Showing reasons for migrant families staying in St. Iould. Reason Number Total 131 Good wages Relatives and Priends here Better Schools Iike it in general Miscellaneous No particular reason

24
7
8
45
4
43

Of those who definitely do not plan to stay in St. Louis, some are moving for much the same reason they came here, the desire to travel or to better their conditions in a general way.

\section{TABLE NUMBER $\nabla$.}

Showing reasons for migrant families not staying in St. Louis.

Reason Number of Families.

Total

Iike south better $\quad 33$

Going north for better wages 4 Homesiok

Poor Heglth in St. Iouis

Don't like oity

High rents

Climate

Hiscelzaneous 
A family of four, with two young children, came here from Memphis seeking better treatment and better schools but were leaving because they were not satisfied with the envirnonment for the children. They lived in a rooming house of doubtful character, with a saloon next door and a pool room in the yard, and can gardly bo blamed for deciding to move to the country. Some are going nprthward with hopes of still higher wages and better industrial opportunities. For example, one family consisting of father and mother and three children under fourteen, came here because their relatives wrote for them. The man was a plumber in New Orleans; here he is a laborer at Swift and Company Paoking House, making $\$ 19.00$ a week, but he is planning to leave st. Iouis because there is no work here for a colored plumber. Another migrant, a jeweler by trade, is leaving because he finds no position in this city open to a negro jeweler. Severak migrants complained of poor health since coming north and for that reason they are returning to the south. occaionally the reason given was that they could not make a living, but this cause was very rare. Moreover all the migrant families who have economic difficulties do not wish to return. A worker of the st. Louis Provident Association, who handles a large number of colored 
cases, states that notn of these in need of assistance are willing to go baok south.

Conditions of Migrants in st. Louis. Description of Negro Sections. There are five pretty well defined negro sections in St. Louis, which Mr. Crossland describes as follows: "The Morgan Street district,.... composed of Morgan and adjacent streets, begings just north of the business section at 8 th street and continues to Ewing. There the district merges with the Market and Pine street distriot, which runs west from Twentieth street to Cardinal and Compton avenues. A large settlement Is forind along the Mill Creek Valley from the Union Station west to Kingshighway. The Elleardsville section extends from Vandeventer to Taylor and from Easton Arenue to Fairground Park. South of this district 1s the Finney Avenue section, which is rapidly growing. These two districts are the residential localities of the well-to-do class of colored people. Carondelet, the extreme southern part of St. Louis, also has a negro settlement $f$ of the Morgan and Market street district, Crossland remarks: "housing conditions are bad; dwellings are orowded together, and rents are high.... A trip through these districts will convince any observant per- 
son that a farge part of the colored people do live wretchedly, under unsanitary conditions, and in dilapidated dwellings."

Housing Conditions.

The majority of the migrants have settled in the most undesirable negro districts, perhaps because og ignorance of the city, or because of financial inablity to live in the better neighborhoods, and it is safe to say that conditions in these poorer sections have not improved materially since Mr. Crossland ade his study. Housing conditions were bad in a large proportion of the cases investigated; not so much actual dilapidation and dangerously bad repair, although there were instances of such conditions, as bad sanitation, poor ventillation, unhealther and filthy yards. It was a common occurrenoe to discover that although there was a tap in the house, it was out of order, and there had been no ranning water for weeks and even for months. This situation is very serious in its effect on the toilet conditions. The most prevalent form of toilet in these districts is that situated in the yard, not a privy vault, but connected with the outside sewer. The waste water from the house and yard hydrahts is the only means of flushing them, and when the water supply is 
out off the condition is practioally that of a vault. Inside toilets and bath tubs are very rare and in almost every case are out of order, so that no benefit is derived from them. In some houses there was staghamt water in the cellar, and the condition in one house was so bad that foul gases came up through tho drain in the sink.

From the point of view of size, many of the yards offered a fair amount of play space for children, but conditions were very poor in most of them. lind, ashes scattered or piled high, garbage and stopped-up drains, such things as these make the yard anything but a heathful and wholesome place to play. It may be argued that these conditions are no worse in negro seotions than in white districts where the lowest types I1ve, but those houses investigated in this study were on the whole wach worse than those of white people in abject poverty, living in very poor neighborhoods. Conditions among migrant negroes are, of course,practically the same as among older residents, except that therermay be more exploitation by landlords.

With respect to overcrowding, especially of the sleeping rooms, we have no available means of comparing conditions among the migrants with the others. However, 
room-overorowaing is very common among the newcomers; often the whole family, father, mother and several children sleep in one room, and lodgers frequently share rooms with children of the family.

Although a few frame houses and quite a number of three story brick houses were found, the most common type of dwelling is the two story brick house. In the Morgan street sections there are many houses divided into apartments, one or two on a floor, but in the Market street district the rooming house type is more prominent.

\section{TABLE NUMBER VI.}

Camulative table showing rents paid by migrant families. (191 cases)

Rent per Month

$\begin{array}{rrr}\$ 2.50 & \text { and } & \text { over } \\ 5.00 & \text { " } \\ 7.50 & " & \text { " } \\ 10.00 & \text { " } \\ 15.00 & " & \text { " } \\ 20.00 & \text { " }\end{array}$

Lumber

191

152

113

71

17

3
Per cent 100 79.5 59.1 36.9

8.9

The rents paid by colored migrants interviewed are on the average higher than those paid by white people for equally desirable houses. Many negro tenants are also compelled to pay more for the same apartment or room than the white tenant previously pald for identically the same; for example, one negro paid \$18.00 a month, while 
the white occupant just before him only paid $\$ 13.00$.

Industrial Conditions.

As far as industrial opportunities are con-

cerned the negro migrants as a rule have bettered their condition by coming here.

\section{TABIE IUIMBER VII.}

Showing the weekly incomes of Migrant families (ID5 families reporting.)

Total weekly incomes Total

$0-\$ 4.99$

$5-9.99$

$10-14.99$

15-19.99

20-24.99

25-34.99

$35-54.99$

$55-109.99$

\begin{tabular}{cc}
\multicolumn{2}{c}{ Present } \\
Number & Per Cent \\
155 & 100 \\
$5-$ & 3.2 \\
18 & 5.2 \\
35 & 22.6 \\
58 & 37.4 \\
27 & 17.4 \\
11 & 7.2 \\
9 & 5.8 \\
$* * 2$ & 1.2
\end{tabular}

*Past Humber Per Cent $128 \quad 82.6$ 2.6 23.2 27.1 16.7 5.2 5.8 2.6 0

* Number not reported are farmers. No money viage. **These two are $\$ 70.00$ and $\$ 109.00$ Some of the leading industries in St. Iouis are the manufacture of brick, lead, iron and steel products, and meat packing, and in all of these the negro is extensively emploped. The lurge steel foundries, lead factories, packing houses and other industrial plants in East St. Louis have been quick to take advantage of the supply of negro labor. Besides the presence of so many industries utilizing negro labor, general economic prosperity and the cutting of ${ }_{1}$ of 
the supply of foreign labor by the present war make industrial opportunities for the negro more plentiful than ever. Among the migrants interviewed there were no cases of unomployment die to inability to find work; the few persons who were not at work were so because of illness or pure laziness.

TABLE NUMBER:VIII.

Showing the number of migrants employed in the leading industries of St. Iouis (258 cases.)

Industries Number Per cent of total number of workers. Total: in' 5 leading ind. 149

Meat

Rallroad

Steel

Brick

Tobacco

53

39

34

17

6
57.7

20.5

15.1

13.2

6.6

2.3

The results of the investigation (See Table number VIII.)

show that the largest groups of workers are in the meat, brick tobacco, lead, steel and railroad industries. Other forms of work are represented by smaller nambers; some of these negroes are teamsters, barbers, ash haulers, plumbers, caal dealers (in a small way) janitors, day laborers, eto. The greater part of the negro migrants are unskilled laborers and it is this group which have the best opportunities for work in St. Louis.

Woman and Child Labor.

Itis quite common for negro women to work to aupplement the income the the man, but the amount of moman labor among themigrants is not very great. The 
reason for this condition may be that the women have not been here long enough to find positions easily. Most of them engage in laundry work, either in private families or in laudries, or in cleaning and cooking. of the younger women, both married and single, a number work in factories, especially the nut factory.

TABIE NUMBER IX.

Showling accupation of Negro Migrant Women in 193 families.

Occupation

Tofal nümbor ëmployed

Iaundress

Housework

Cooking

Nut Factory

Boarding Housekeeper

Housekeeper

Landlady

Teacher

Miscellaneous
Number

Present Past

$55 \quad 66$

$23 \quad 28$

$8 \quad 11$

$3 \quad 15$

111

32

21

, I

$4 \quad \frac{7}{7}$

Child labor is very uncommon among the megroes. Many young persons over sixteen work, but only occasionally do we find one under that age in industry. In all probability this fact is due to lack of opportunities for colored children to work.

Previous Occupation.

With respect to the occupations of the migrants in their previous place of residence, it is interesting to note the changes. A considerable proportion of the men from the south were farmers, and little definite in- 
formation could be obtained about the days and hours of work, and remuneration, probably because the arrangements were very indefinite. Some owned their own farms, others received rent and subsistence in return for cultivating the land, and others paid the rent in produce.

\section{TABLE NUMBER $X$.}

Showing accupation of migrant men (258 cases.)

$\begin{array}{lcr}\text { Occupation } & \text { Present } & \text { Past } \\ \text { Tatal } & 258 & 267 \\ \text { Packing Co. Employes } & 53 & 12 \\ \text { Railood } & 39 & 26 \\ \text { Steel Plant " } & 34 & \\ \text { Brick Mf.Co. " } & 17 & \\ \text { Tobacco Factory" } & 6 & 7 \\ \text { Fireman } & 4 & 60 \\ \text { Drivers } & 3 & 75 \\ \text { Farmers } & & 12 \\ \text { Iaborers(industry not specified) } & 49 & 4 \\ \text { Porter } & & 61 \\ \text { Janitor } & & \\ \text { Miscellanedas } & 53 & \end{array}$

Many migrants were laborers before and various occupations are represented. Of the East St. Louis negroes, many have kept their same occupation and same position, but not reside on this side of the river. In general, working conditions here are superior to those in the south; and especially are the hours shorter and more definite. 
TABIE NTIBBER XI

Showing number of hours work per day of migrant negroes, (153 cases reported.)

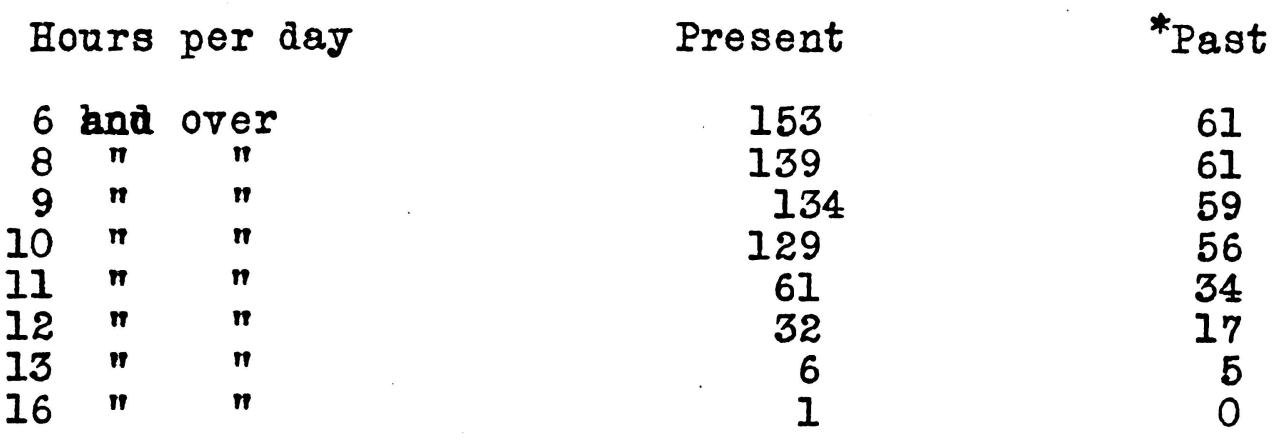

* The large number of cases where no report was made on the hours per day in past occupation, the man was a farmer and had irregular hours, long in most cases.

The proportion of women working is not so high here as in the place of last residence; about thirty four percent were emplojed befofe, and now approximately twenty eight per cent of the women work.

Education.

In $1916 \mathrm{st.} \mathrm{Iouis} \mathrm{had} \mathrm{for} \mathrm{the} \mathrm{negro} \mathrm{ten} \mathrm{elemen-}$ tary schools, one special school for subnormal children and one high sohool; i on 1917; an adaitional grade school, the Iincoln, was opened. The equipment is falrlygood, and two of the schools especially, the simmons and Sumner High School, which are located in the better residential district, are up-tomate in faollities and management. The registration in the colored schools has increased amazingly in the last year; the new Iincoln School had a 
resgistration of 826 in September 1917 and in February 1918, the regstration had increased to 994. The other schools all show a decided increase in proportion to their size.

TABIE NUIBER XII.

*Showing increase in registration of the colored schools of st. Iouis.

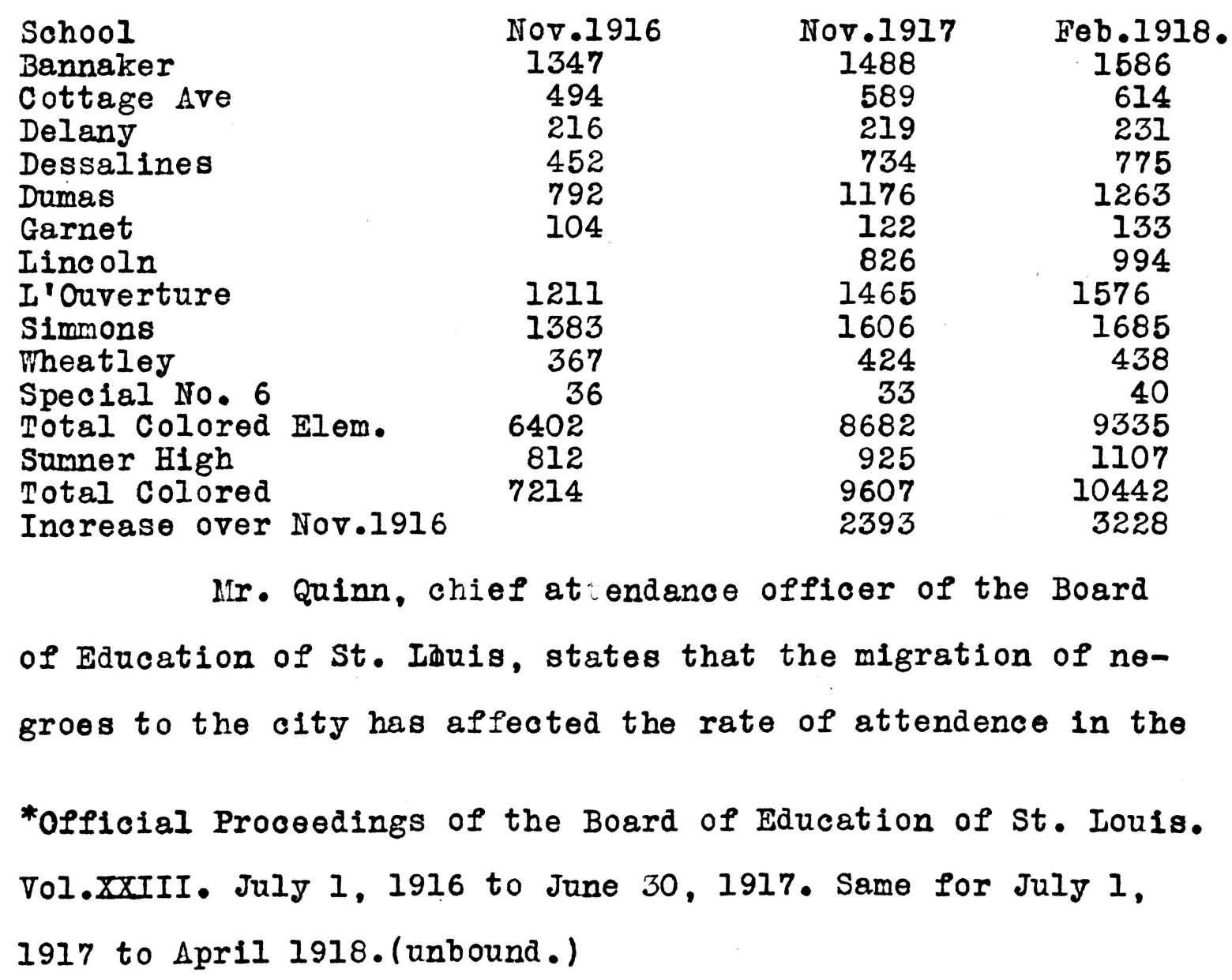


colored schools. The influx necessitated the closing of the Iincoln School for white children and opening it for colored; thid accomodated only a small part of the inorease, and the remainder was distributed among the other sohools. All the sohools have suffered a decrease in the attendence rate; for example, in the Bannaker School in 1917 the attendence was 75 per cent of the registration; in 1018 it was slightly less than 70 per cent. The attendence officers attribute this decrease to two causes: the sewere winter, and the migration. The newcomers from the south were accustome to low educational standards, low standards of living, and the change from raral to urban life presents maladjustments. Int the poorer districts, where home conditions are worst, education has not a very strong appeal, and the pressure of the law is necessary tp enforce attendance. Mr. Quinn feels that edueation of the negro is possible of achievement only by alming to raise the standards of living and the conception of duties toward the community.

The investigation of migrant families shows that the poor sohool facilities of the south have greatly retarded the pregress of the chlldren. Often several children in a family will be in the same grade, even when there are several jears difference in their ages. 
Religious facilities.

The colored church facilities in the city are fairly adequate, but many migrants have not come in contact with them. It is difficult to obtain definite information as to church attendence, but the faot that many do not even know where the nearest church 1s, is rather significant. One very religious colored woman, who has lived here all her life, expressed her opinion of the newcomers - which, it might be said, was rather hasty and not based on substantial facts, but on impressions - Mou won't find many o' those new niggers in the churchs - when they gits up here'stead o' using all the good opportunities they goes the wrong way, and'stead $0^{\prime}$ thankin' the Lord for bringin" em to a good place, they jes' drops him. Down south they had to depend on the Lord, 'cause that was all they had to depend on." However, Miss Moore, whom we have previousIf quoted, has a more optimistic view of the religious situation, and feels that the migrant negroes are at heart just as pious as amy of the race.

\section{Recreation.}

The facilities for recreation for the negro are very inadequate in $9 \mathrm{t}$. Louis. Playgrounds are especially needed in the districts in which the colored people live because of the had conditions of the yards and streets. But only one plagground, that at oth and Carr streets, is 
open to colored as well, as to white children. At Twentythird and Pine there is an improvised pleyground, lat used in the winter as a minicipal coal yard; this one is for the exclusive use of colored children. These two are the only playgrounds designated by the city for the use of the negro, but some of the others may be used at certain times. Negroes are allowed in the small parks or squares in these districts, but often these are not near enough to be accessible, and they do not serve quite the same constructive purpose that playgrounds serve. It is evident that little thought is given to the recreational needs of colored children; few social agencies offer opportunity for fecreation to the colored people, and the only social centers for them are the Iincoln School Mound city Settlement, and the colored Y. M. C. A. and Y. W. C. A. These two latter organizations do a great deal of constructive work, but do not reach the people in the poorer districts where most of the migrants 11ve.

St. Louis has one free dance hall for negroes, but with this exception all amusements of that sort are commercialized. There are five moving picture theatres for negroes, four of them on Market Street, and one on Franklin Avenue, in the Horgan Street district. The Ignorance displayed by the migrants with regard to the various recreational facilities shows that they do not derive much behofit from them. Very 
few know of any social agency or social center and the locations of parks, playgrounds, halls and moving picture shows were often unknown to them. It is discouraging to note, however, that every migrant knew about the nearest saloon, possibly because there always was one very near. In the course of the investigation no family was found living more than one block from a saloom, and often there were as many as four or five in one block. In the presence of such a great array of destructive forces the need for constructive work is mouh more urgent.

\section{Health.}

It is impossible inthis stady to compare the health of migrant negroes with that of older residents, but some idea can be obtained as to the general conditions. The migrants from the south frequently spoke of the effect of the northern climate on their health; they have suffered from severe colds, la grippe, and general poor health, and many families have had more than their share of serious illness. One family, consisting of the mother, father and three small children, seemed to be 1ll-adapted to conditions and climate here, and were planning to return south as soon as soon as possible. They had been in st. Iouls only one year, and in that time have had one death, one case of tuberculo4. and six other cases of sertus sickness. The experience 
of the investigators resulted in the impression that the health of the migrant negroes was below the average. It is not to be wondered at,if these people suffer feom 111 health, when we consider the unsanitary and crowded condip tions in which they live, and the difference in climate for those who have come from the south. The combination of these two conditions is very serdous because susceptibility to bad housing and bad sanitation is so much greater among those people who have not become hardened to the severer weather. Among Seventy five families in the Warket street district who had come from the south, about half had had no serious illness; in the other half (35 familles) there had been five deathe, five cases of Tuberculosis, and fifty four other cases of severe siokness since their arrital in st. Iouis.

Facilities for medical treatment of the negro are very limited in St. Louis. As. has been sald, post of the hospitals are closed to negroes even when they can afford to pay. Dr. Baileg's negro hospital is small, poorly equipped and not efficiently managed Barnes Hospltal has a ward for negroes, and the City Hospital, and its aivisions, Koch hospital, the Isolation Hospital, Quatantine and Municipal dispensaries, admit negroes. Recently two baby clininc have been established for colored babies, and 
it is hoped that this work will spread rapdily. With regard to the adequacy of the number of colored physicians, Crossland*estimated in 1914 that there was ono physician for every 2000 negroes; this means a large field foe each one, and as that authority says, "there is much sickness among the colored people and a great needi of health improvement in the race." The St. Louls Visiting Nuree Association is doing extensive work among the negroes in oonnection with the Metropolitan Life Insurance Company; their work is very valuable to the hegroes and to the community.

At present there are no openair schools for negroes children who are pre-tuberculor, or are pre-disposed to the disease, but the Board of Education expects to open one in september 1918. The need far open air. schools for colored children, is very great, since the negro death rate from tuberculosis is** four times that of the whites.

*Crossland, Wm. A. Ind. Cond, among Negroes in St. Iouisp. 39. **Computed from health reports for 1915. 


\section{Prohlems of Community Interest Aggravated by the Negro Migration \\ Bad Housing Conditions.}

The unusual volume of negro migration to st. Iouis has made the problem of housing conditions more serious than ever. The demand for dwellings means that every possible building will be pressed into service whether sutable for living purposes or not. It is probable that the migrants take whatever they can get in the way of housing accomodations, and under these clrcumstances there is little stimulus for the owbers and agents to improve the conditions of their buildings. Bad housing has such a decided influence on health, and also effects the habits, morals and character of the people to such an extent that it must not be 1gnored.

\section{Inadequacy of Constructive Forees.}

Better recreational facilities in those districts where the migrant negroes have largely congregated would make the problems of malad justment much simpler. Those who come from country districts in the south find it especially difficult to make the necessary change in customs and standa ards. Wholesome recreation, through parksis pajgrounds and social centers, will do much readjust the migrants to 
the new conditions surrounding them, and to keep them out of trouble. The young people especially need direction of their energy along wholesome lines; when ignorant if city life they are attracted by commercialized amusements of a demoralizing nature, and through them often receive the first influence that lead to juvenile deliquency, crime and degeneration. The lack of constructive work among the negroes is a serolus problem, and must receive the attention of soclal workers and others who can use their influence to better condtion Without these constructive forces, destructive influences will be froe to undermine the standards and the morals of the people and retard the development of intelligent, upright citizens.

\section{Recomendations for Improving the conditions of Migrant Negtoes in St. Louis. \\ One of the fost important fields for improve-} ment is that of housing; a campaign for better legislation and for more thorough falfillment of the existing laws would be a good starting point, bat the problem is one that will require jears untiring effort on the part of those who realize its importance.

The need of more adequate recreational faciltties should receive immediate attention. There should be more parks and playgrounds in the negro districts, not necessarily for colored people exclusively, but at least 
allowing the two races equal access to them. Soctal centers for the negro have great possibilities and are soreIy needed. By using several of the schools for this purpose a vast amount of constructive work could be accomplished; the churches also should take a hand in this kind of work. In view of the ignorance of church facilities vhown by a great number of the migrants, it might be worth while for the church/to make an effort to enlist the interest and support of these newcomers.

Until the private gospitals of St. Louis change their policy and admit negroes, as $B_{\text {arnes Hospital now }}$ does, there is great need of an efficient modern hospital for negroes alone. More physicians are needed to cope with the health problems of this people, and opportunities in this profession open to negroes should he emphasized in a way to attract intelligent colored persons.

Before satisfactory work can be done to improve conditions of the negro, agencies dealing with them must keep better, more complete records. Social agencles like the St. Iouis Provident Assooiation and the Anti-TubercuIosis Society and all public departments should keep a separate statistics of white and colored cases. Educational statistics are very satisfactory in that respect, since the races are naturally separated in the schools. On the other 
hand, no information of value to this study was obtainable from the courts, the police reports, the Provident Association or the Visiting Burse Association, because separate records of white and colored cases were not abailable. Until it is made possible, by the perfecting of records and reports of all organizations dealing with the negro, to ascertain present conditions and problems, constructive work will be greatly hampered.

The south is waking up to the fact that there is a negro problem, and white and colored leaders are earnestly trying to define the causes and remedy conditions. The conference in Nashville, Tennessee, and the Southern Sociological Congress which was recently at Birmingham, Alabama, devoted part of the time to discussion of the relations between the raoes. *The frankness and sympathy with wheih the leaders of both races discusses their problems, and the growIng desire of the whites to do their part to secure better treatment for the negro, are hopeful signs of a more harmonlous relation between the races. The problem in the south is to remedy those conditions which are driving the negro northward. The north has a different problem; to see to it: that the migrants receive the fair treatment, justice

*The Survery-Editorial May 11, 1918. 
and educational advantages they are seeking, and that their maladjustments here are righted as speedily as possible for the good of the community as well as of the $n$ newc omers.

In conclusion, we feel that Professor Haynes has outlined a pplendid program for constructife work among the negroes; *opportunity for training in general intelligence and for full experience in all the business, professional, philanthropic and civic affairs of community life should be afforded the large number of capable negroes now eager to serve their people and their country."

*INegtoes More North. The Survey, May 4, 1918. pl22. 


\section{BIBLIOGRAPHY.}

I. Books.

Crossland, Williamd August. Industrial Conditions Among Negroes in st. Iouis. Edited by the School of Sooial Economy of Washington University, st. Louis, 1914. Epstein, Abraham. The Negro Migrant in Pittsburg. Published by the School of Economics, University of Pittsturg. Pittsburg, Pa. 1918.

II. Periodicals.

Haynes, George Edmund. Negroes Move North. The Survey; Volume 40, May 4th, 1918.pp.115-122. Editorial. The Survey, Volume 40, May llth, 1918.

III. Reports.

Boari of Education - 56th Annual Report. pp. 270-73. Bard of Education - Official Proceedings. Vol. ume XXIII. July 1st, 1916, to June 30th,1917. Board of Education - Official Proceedings, July lst, 1917 to April 1918. (unbound) 
$378.7 M 71$

Xs+59

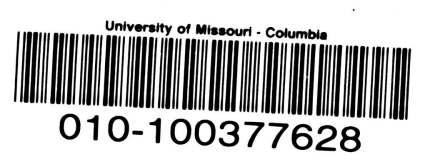


MU Libraries

St ith1918SpecSheet, txt

University of Missouri-.-Col umbia

MU Theses and Dissertations (Pre-1920)

Local identifier

Capture information

Date captured

Scanner manufacturer

Scanner model

Scanning system software

Optical resolution

Color settings

File types

Source information

For mat

Content type

Source I D

Notes
St ith1918

20170713

Zeutschel

OS 15000

Omniscan v.12.8 SR2 (2675)

$600 \mathrm{dpi}$

grayscale, 8 bit

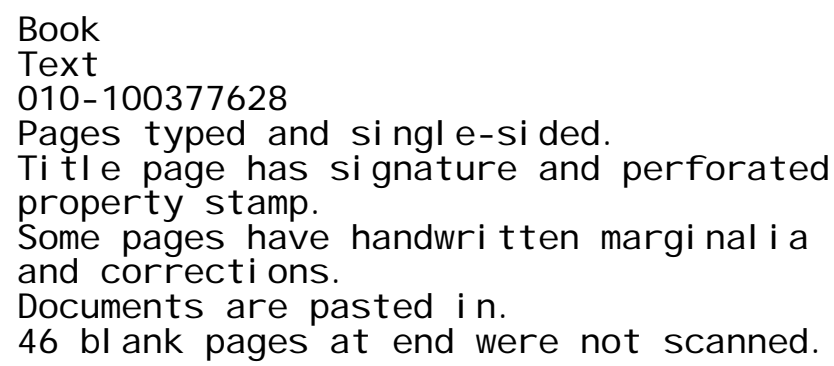

$010-100377628$

Pages typed and single-sided.

Title page has signature and perforated property stamp.

Some pages have handwritten margi nalia and corrections.

Documents are pasted in.

46 blank pages at end were not scanned.

Derivatives - Access copy

Compression

Editing soft ware

Resolution

Color

File types

Notes

Tiff compressed with LZW before conversion to pdf Adobe Photoshop CS5

$600 \mathrm{dpi}$

Grayscale

$p d f$

Grayscale pages cropped, canvassed,

and i mages brightened.

Bl ank pages removed.

Canvas size: $8 \times 11$ 